\title{
Satisfaction Level of Rural Women towards Vocational Training in Two Districts of Haryana, India
}

\author{
Twinkle $^{1 *}$, Kusum Rana ${ }^{1}$, Kiran Singh ${ }^{1}$ and Jatesh Kathpalia ${ }^{2}$ \\ ${ }^{1}$ Department of Family Resource Management, ${ }^{2}$ Department of Sociology, \\ CCS Haryana Agricultural University, Hisar, Haryana, India 125001 \\ *Corresponding author
}

\begin{tabular}{l} 
Ke y w o r d s \\
Vocational training, \\
$\begin{array}{l}\text { Satisfaction level, } \\
\text { Women, Eco- } \\
\text { friendly articles }\end{array}$ \\
\hline Article Info \\
\hline $\begin{array}{l}\text { Accepted: } \\
\text { 20 May } 2020 \\
\text { Available Online: } \\
\text { 10 June } 2020\end{array}$ \\
\hline
\end{tabular}

\section{A B S T R A C T}

Training is a vital tool to attain, sustain and accelerate the pace of development. To keep abreast of fast-changing technological developments, the skills of human resources are also required to be continuously updated through training and development. The efforts are being made in the country to enable women to play a greater role in development. Supply services like nutrition, health, up-gradation skills, income generation assets and opportunities for employment are being provided through various governmental programmes. The study was conducted in four villages of Jhajjar and Hisar districts of Haryana state purposively. A batch of enthusiastic and willing to participate 25-30 rural women were selected. Satisfaction level of training was measured in term of subject matter covered in the specific training, physical facilities provided during the training and quality of trainer. Weighted mean score and ranks were used for estimating of data related to satisfaction level of respondents. Respondents were highly satisfied (2.73) with the subject matter covered during the training, quality of trainer (2.76) and physical facilities (2.72) were considered to be highly satisfactory by them.

\section{Introduction}

Training is a vital tool to attain, sustain and accelerate the pace of development. To keep abreast of fast-changing technological developments, the skills of human resources are also required to be continuously updated through training and development. The significance of training and education for improving the standard of living of a family, especially through homemakers has been recognized long back but has gained impetus only in the recent past. The importance of training for women empowerment has further gained the attention of policy makers in our country. With fast emerging sophisticated innovations and technologies in every field, training is increasingly becoming a potent instrument that can help people bring about improvement in their prevailing conditions and ways of making a living (Anita, 2006). 
Women form a significant proportion of the work force in India. However, they are largely concentrated in the informal sector, engaged in vocations characterized by low earning, low productivity, poor working conditions and lack of social protection. One of the serious problems that they face is poor quality of work. The efforts are being made in the country to enable women to play a greater role in development. Supply services like nutrition, health, up-gradation skills, income generation assets and opportunities for employment are being provided through various governmental programmes (Pande, 2015).

Keeping the importance of vocational trainings in view, the present study was conducted with the following specific objectives: Effectiveness of training through satisfaction level of respondents in terms of subject matter, physical facilities and quality of trainer.

\section{Materials and Methods}

The study was conducted in four villages of Jhajjar and Hisar districts of Haryana state purposively. Ukhalchana Kot (V1) and Badhani (V2) villages were selected form Jhajjar and Mangali (V3) and Gawad (V4) villages were selected from Hisar for the present study.

A batch of enthusiastic and willing 25-30 rural women willing to participate and start their enterprise after acquiring skill by attending vocational training programme on eco-friendly decorative and utility items for home and festivals were selected. Five days vocational training on eco-friendly decorative and utility items for home and festivals were imparted to women in selected villages through demonstration, lectures and handson-experience in order to enable them to prepare items, do their value addition, packaging and explore markets for income generation.

Satisfaction level of training was measured in term of subject matter covered in the specific training, physical facilities provided during the training and quality of trainer. Thus overall satisfaction level was calculated by total of all three aspects that is subject matter, Physical facilities and qualities of trainer, of each component.

Weighted mean score and ranks: were used for estimating of data related to satisfaction level of respondents.

\section{Results and Discussion}

\section{Satisfaction level of the respondents} towards trainings

It was measured in terms of following parameters and the findings are explained accordingly.

\section{Subject Matter \\ Physical facilities \\ Quality of trainer}

\section{Subject matter}

With regard to perception of respondents about subject matter of training programme (Table 1), it is observed that respondents were highly satisfied about the subject matter during training programme. Almost similar scores were observed for two villages of Jhajjar and two villages of Hisar separately indicating relevance of subject matter covered during training.

\section{Physical facilities}

Respondents were highly satisfied with the physical facilities provided at the time of the trainings. Perception of women about 
physical facilities used during trainings (Table-2) with proper sitting arrangement during training (2.90 W.M.S. ranked I), convenient venue (2.85 W.M.S. ranked II), demonstration facilities (2.71 W.M.S. ranked III), supply of training inputs (2.66 W.M.S. ranked IV) and post training facilities (2.50 W.M.S. ranked V) respectively.

\section{Quality of trainer}

It is observed in Table- 3 that the respondents were satisfied with the quality of the trainer in respect of effective communication skills (2.83 W.M.S. ranked I), confidence (2.82 W.M.S. ranked II), interest of trainer (2.79 W.M.S. ranked III), adequate knowledge of the subject (2.78 W.M.S. ranked IV), experienced trainer (2.77 W.M.S. ranked V), clarity in expression (2.77 W.M.S. ranked $\mathrm{VI})$, teach one idea at a time (2.75 W.M.S. ranked VII) and cordial relation and oriented to field problem had same weighted mean score and shared same rank (2.70 W.M.S. ranked VIII) respectively.

\section{Overall satisfaction level}

Table-4 depicts that respondents were found to be satisfied with the trainings. Results indicated that the respondents were highly satisfied with the quality of trainer within all the four trainings. In case of subject matter taught to them or covered, the respondents were completely satisfied and same goes in the case of physical facilities provided to them during the trainings.

Table.1 Perception of women about subject matter of trainings

\begin{tabular}{|l|l|l|l|l|l|l|l|}
\hline $\begin{array}{l}\text { Sr. } \\
\text { No. }\end{array}$ & Parameters & $\begin{array}{l}\text { Jhajjar } \\
\text { (V1) } \\
\text { n=25 }\end{array}$ & $\begin{array}{l}\text { Jhajjar } \\
\text { (V2) } \\
\mathbf{n = 2 5}\end{array}$ & $\begin{array}{l}\text { Hisar } \\
\text { (V3) } \\
\mathbf{n = 2 5}\end{array}$ & $\begin{array}{l}\text { Hisar } \\
\text { (V4) } \\
\mathbf{n = 2 5}\end{array}$ & $\begin{array}{l}\text { Total } \\
\text { N=100 }\end{array}$ & Rank \\
\hline 1. & Relevant to trainees need & 2.88 & 2.82 & 2.80 & 2.80 & 2.82 & I \\
\hline 2. & Training content comprehensive & 2.92 & 2.80 & 2.76 & 2.56 & 2.76 & IV \\
\hline 3. & Practical utility & 2.96 & 3.00 & 2.64 & 2.56 & 2.79 & II \\
\hline 4. & Timely & 2.80 & 2.92 & 2.60 & 2.36 & 2.67 & VII \\
\hline 5. & Useful to trainees & 2.84 & 2.88 & 2.52 & 2.48 & 2.68 & VI \\
\hline 6. & Properly understood by trainees & 2.82 & 2.96 & 2.48 & 2.52 & 2.69 & V \\
\hline 7. & Appropriate subject matter & 2.86 & 2.84 & 2.72 & 2.68 & 2.77 & III \\
\hline
\end{tabular}

Table.2 Perception of women about Physical facilities

\begin{tabular}{|l|l|l|l|l|l|l|l|}
\hline $\begin{array}{l}\text { Sr. } \\
\text { No. }\end{array}$ & Parameters & $\begin{array}{l}\text { Jhajjar } \\
\text { (V1) } \\
\mathbf{n = 2 5}\end{array}$ & $\begin{array}{l}\text { Jhajjar } \\
\mathbf{( V 2 )} \\
\mathbf{n = 2 5}\end{array}$ & $\begin{array}{l}\text { Hisar } \\
\text { (V3) } \\
\mathbf{n = 2 5}\end{array}$ & $\begin{array}{l}\text { Hisar } \\
(\mathbf{V 4}) \\
\mathbf{n = 2 5}\end{array}$ & $\begin{array}{l}\text { Total } \\
\text { N=100 }\end{array}$ & Rank \\
\hline 1. & Proper sitting arrangement & 2.92 & 2.96 & 2.88 & 2.84 & 2.90 & I \\
\hline 2. & Convenient venue & 2.88 & 2.92 & 2.80 & 2.80 & 2.85 & II \\
\hline 3. & Supply of training inputs & 2.80 & 2.76 & 2.60 & 2.48 & 2.66 & IV \\
\hline 4. & Demonstration facilities & 3.00 & 2.90 & 2.56 & 2.40 & 2.71 & III \\
\hline 5. & Post training support facilities & 2.78 & 2.88 & 2.20 & 2.16 & 2.50 & V \\
\hline
\end{tabular}


Table.3 Quality of trainer of the trainings (Feedback of the trainer)

\begin{tabular}{|c|c|c|c|c|c|c|c|}
\hline $\begin{array}{l}\text { Sr. } \\
\text { No. }\end{array}$ & Parameters & $\begin{array}{l}\text { Jhajjar } \\
\text { (V1) } \\
\text { n=25 }\end{array}$ & $\begin{array}{l}\text { Jhajjar } \\
\text { (V2) } \\
\text { n=25 }\end{array}$ & $\begin{array}{l}\text { Hisar } \\
(\mathrm{V} 3) \\
\mathrm{n}=25\end{array}$ & $\begin{array}{l}\text { Hisar } \\
(\mathrm{V4}) \\
\mathrm{n}=25\end{array}$ & $\begin{array}{l}\text { Total } \\
\mathbf{n}=\mathbf{1 0 0}\end{array}$ & Rank \\
\hline 1. & Interest of the trainer & 2.96 & 2.90 & 2.64 & 2.64 & 2.79 & III \\
\hline 2. & $\begin{array}{l}\text { Adequate knowledge of the } \\
\text { subject }\end{array}$ & 3.00 & 2.96 & 2.60 & 2.52 & 2.78 & IV \\
\hline 3. & Clarity in expression & 2.92 & 2.84 & 2.62 & 2.72 & 2.76 & VI \\
\hline 4. & Cordial relation & 2.76 & 2.88 & 2.56 & 2.60 & 2.70 & VIII \\
\hline 5. & Confidence & 2.92 & 2.72 & 2.76 & 2.88 & 2.82 & II \\
\hline 6. & Teach one idea at a time & 2.80 & 2.76 & 2.76 & 2.70 & 2.75 & VII \\
\hline 7. & Experienced trainer & 3.00 & 2.78 & 2.68 & 2.62 & 2.77 & $\mathbf{V}$ \\
\hline 8. & Oriented to field problem & 2.84 & 2.80 & 2.48 & 2.68 & 2.70 & VIII \\
\hline 9. & Effective communication & 2.82 & 2.84 & 2.84 & 2.84 & 2.83 & I \\
\hline
\end{tabular}

Table.4 Overall satisfaction of women towards trainings

\begin{tabular}{|c|c|c|c|c|c|c|}
\hline $\begin{array}{l}\text { Sr. } \\
\text { No. }\end{array}$ & Aspects & $\begin{array}{l}\text { Jhajjar } \\
\text { (V1) } \\
\text { W.M.S } \\
\text { n=25 }\end{array}$ & $\begin{array}{l}\text { Jhajjar } \\
\text { (V2) } \\
\text { W.M.S } \\
\text { n=25 }\end{array}$ & $\begin{array}{l}\text { Hisar } \\
\text { (V3) } \\
\text { W.M.S } \\
\text { n=25 }\end{array}$ & $\begin{array}{l}\text { Hisar } \\
\text { (V4) } \\
\text { W.M.S } \\
\text { n=25 }\end{array}$ & $\begin{array}{l}\text { Total } \\
\mathbf{n}=\mathbf{1 0 0}\end{array}$ \\
\hline 1. & Subject matter & 2.86 & 2.88 & 2.64 & 2.56 & 2.73 \\
\hline 2. & Quality of trainer & 2.89 & 2.83 & 2.66 & 2.68 & 2.76 \\
\hline 2. & Physical facilities & 2.87 & 2.88 & 2.60 & 2.53 & 2.72 \\
\hline
\end{tabular}

Fig.1 Overall satisfaction of women towards trainings

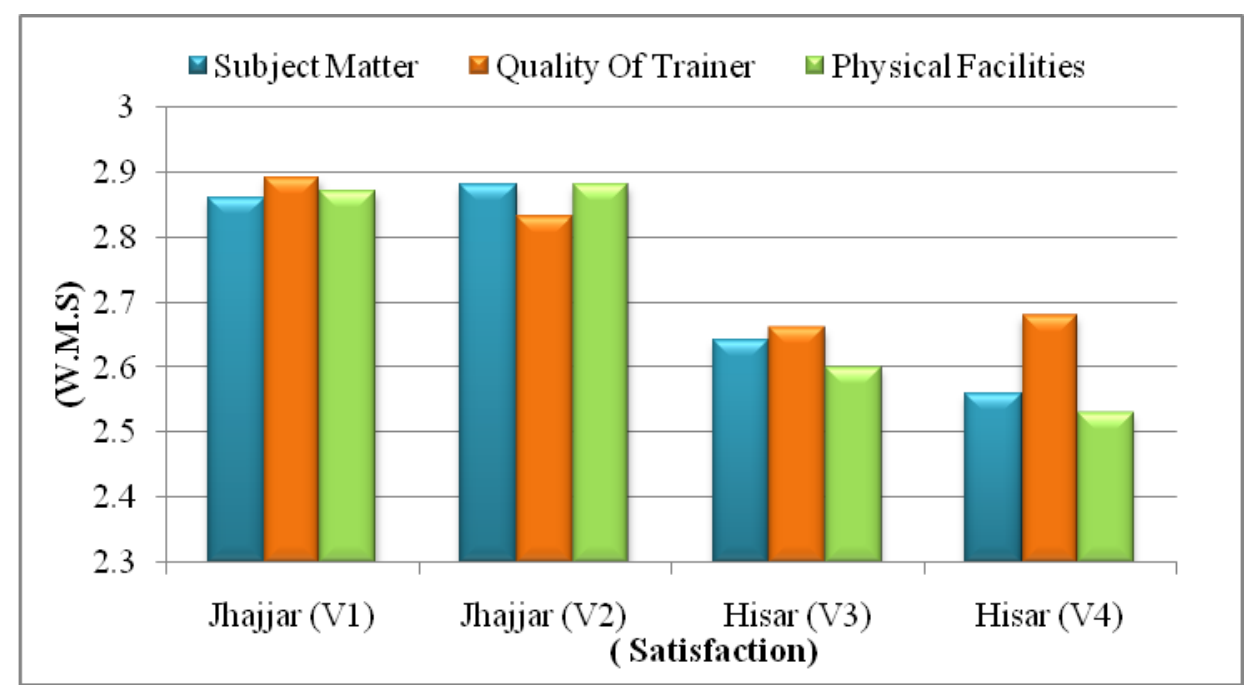




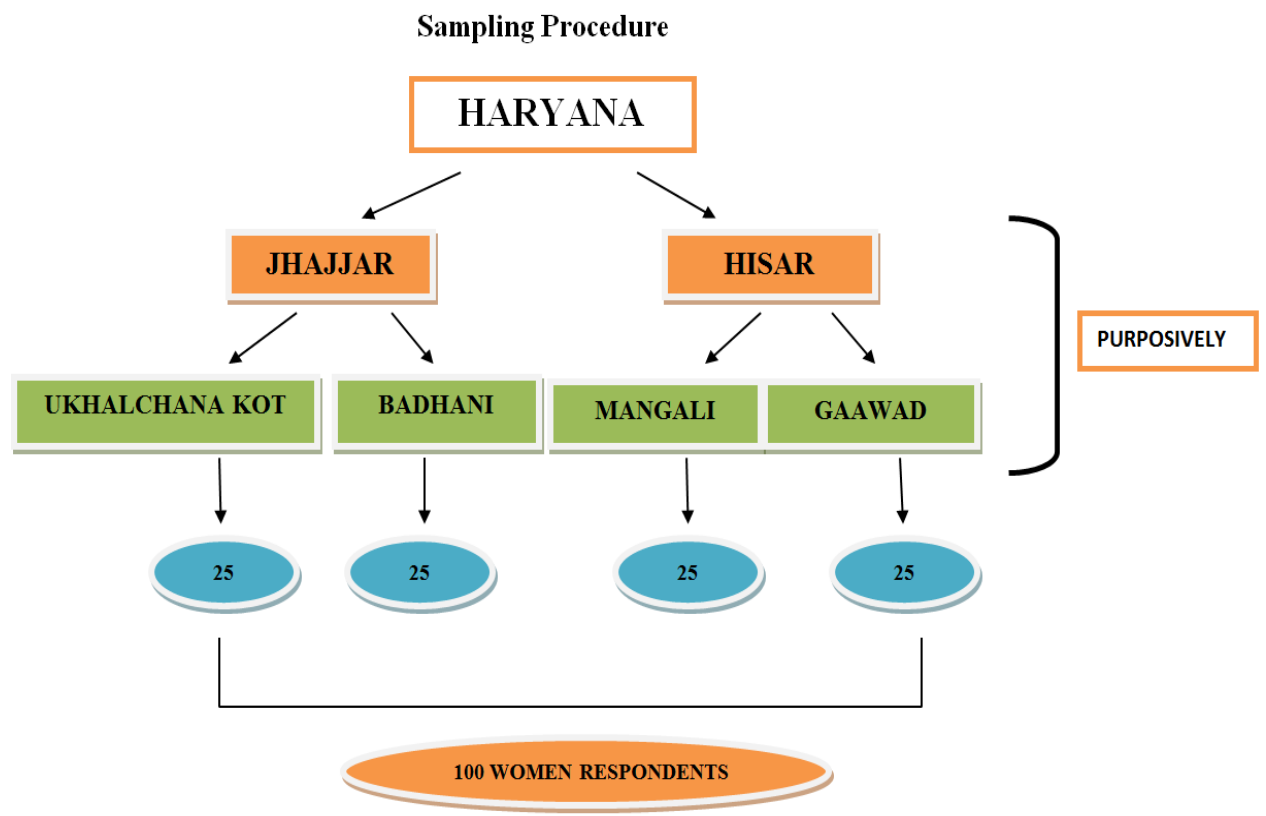

Conclusion and discussion are as follows

Women respondents were highly satisfied towards vocational trainings. It is also indicated that women respondents were satisfied about the physical facilities provided, subject matter covered and quality of trainer during the trainings.

Respondents were highly satisfied (2.73) with the subject matter covered during the training, quality of trainer (2.76) and physical facilities (2.72) were considered to be highly satisfactory by them.

Women respondents were highly satisfied towards vocational trainings. It is also indicated that women respondents were satisfied about the physical facilities provided, subject matter covered and quality of trainer during the trainings. Respondents were highly satisfied (2.73) with the subject matter covered during the training, quality of trainer (2.76) and physical facilities (2.72) were considered to be highly satisfactory by them. The study of Kiran Bala (2016) supported the study.

\section{References}

Anita (2006) Assessment of institutionalized Home Science trainings at CCS Haryana Agricultural University, Hisar. Master's Thesis, CCS Haryana Agricultural University, Hisar.

Anon (2013) In: Benefits of vocational education and training in Europe for people, organization and countries, European Centre for the Development of Vocational Training. Publications Office of the European Union, Luxembourg.

Davi, V. and Shaik, N. (2012) Evaluating training and development effectivenessA measurement model. Asian Journal of Management Research, 2(1), 22-35.

Bala, K. (2016) Impact assessment of Cutting and Tailoring Trainings organized by KVK for Schedule Caste Women. M.Sc. Thesis, CCS Haryana Agricultural University, Hisar.

Pande, R (2015) Education, employment and women empowerment. Contemporary Social Sciences, 24(4), 89-94.

Shukla, N. and Singh, A.R. (2010) Effectiveness of distance education 
package on value added product from fruits and vegetables. Indian Res. J. Ext. Edu. 10(2): 55-57.

Veerajaneyulu, K., Krishnaveni, G. Lakpathi, G. and Rajanikanth P. (2014) Skill development and enhanced livelihood opportunities through apparel making and embroidery trainings $\mathrm{KVK}$, Kampasagar, Nalgonda District. International Journal of Scientific \& Technology Research, 3(1):1-10.

\section{How to cite this article:}

Twinkle, Kusum Rana, Kiran Singh and Jatesh Kathpalia. 2020. Satisfaction Level of Rural Women towards Vocational Training in Two Districts of Haryana, India. Int.J.Curr.Microbiol.App.Sci. 9(06): 2727-2732. doi: https://doi.org/10.20546/ijcmas.2020.906.331 